\title{
The quantitative proteomic response of Synechocystis sp. PCC6803 to phosphate acclimation
}

\author{
Matthew A Fuszard', Saw Yen Ow², Chee Sian Gan³, Josseilin Noirel², Nigel G Ternan , Geoff McMullan ${ }^{4}$, \\ Catherine A Biggs ${ }^{2}$, Kenneth F Reardon ${ }^{5}$ and Phillip C Wright ${ }^{2^{*}}$
}

\begin{abstract}
Background: Inorganic phosphate $\left(P_{i}\right)$ is a critical nutrient for all life and is periodically limiting in marine and freshwater provinces, yet little is understood how organisms acclimate to fluctuations in $\mathrm{P}_{\mathrm{i}}$ within their environment. To investigate whole cell adaptation, we grew Synechocystis sp. PCC6803, a model freshwater cyanobacterium, in 3\%, and $0.3 \%$ inorganic phosphate $\left(P_{\mathrm{i}}\right)$ media. The cells were allowed to acclimate over 60 days, and cells were harvested for quantitative high throughput mass spectrometry-based proteomics using the iTRAQ ${ }^{\text {TM }}$ labelling technology.
\end{abstract}

Results: In total, 120 proteins were identified, and 52 proteins were considered differentially abundant compared to the control. Alkaline phosphatase (APase) activities correlated significantly $(p<0.05)$ with observed relative PhoA abundances. PstS1 and PstS2 were both observed, yet PstS1 was not differentially more abundant than the control. Phycobilisome protein abundances appeared to be coordinated, and are significantly less abundant in $0.3 \% \mathrm{P}_{\mathrm{i}}$ than $3 \% \mathrm{P}_{\mathrm{i}}$ cultures. Also, the central metabolic cell function appears to have shifted towards the production of (NADPH) reducing energy and nucleotide sugars.

Conclusions: This acclimation response bears strong similarity to the previously reported response to nitrogen deprivation within Synechocystis sp. PCC 6803. However, it also demonstrates some characteristics of desiccation stress, such as the regulation of fatty acids and increased abundance of rehydrin in the $3 \% \mathrm{P}_{\mathrm{i}}$ culture.

Keywords: Cyanobacteria, iTRAQ, Phosphate acclimation, Phycobilisome, Pentose phosphate pathway, Ribose sugars, Synechocystis

\section{Background}

Cyanobacteria comprise one of the largest groups of prokaryotes. They are found in a wide variety of niches, including terrestrial and hypersaline environments, and in oceans, lakes and rivers. Synechocystis sp. PCC 6803 (hereafter Synechocystis), a model freshwater cyanobacterium, has strong potential biotechnology applications in areas as diverse as biofuels [1], biopolymers [2] and other secondary metabolites [3]. Due to this biotechnological interest, its general applicability as a model organism for $\mathrm{CO}_{2}$ fixation and environmental stress

\footnotetext{
* Correspondence: p.c.wright@sheffield.ac.uk

${ }^{2}$ ChELSI Institute, Department of Chemical and Biological Engineering, University of Sheffield, Sheffield S1 3JD, UK

Full list of author information is available at the end of the article
}

responses has been the subject of post-genomic investigations [4-8], including proteomics investigations using both 2-DE [8] and shotgun proteomics workflows [7].

For most microorganisms, the preferred source of the essential nutrient phosphorus is inorganic phosphate $\left(P_{i}\right)$. However, phosphate is the planet's least abundant naturally occurring mineral [9]. $\mathrm{P}_{\mathrm{i}}$ limitation occurs for sustained periods in many geographically dispersed freshwater lakes and marine sites. To date, however, there have been relatively few investigations into the cell-wide response of microorganisms to this form of nutrient stress, particularly over longer periods that reflect adaptation rather than short-term response. An understanding of these processes will be of use not only

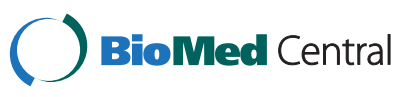


in the basic understanding of microbes and the niches they occupy, but could also be applied to develop biomarkers to follow stages in the phosphorus biogeochemical cycle within aquatic environments. In addition, the identification of novel proteins associated with $\mathrm{P}_{\mathrm{i}} \mathrm{up}$ take could be exploited in the removal of $P_{i}$ for water quality improvement, whilst enzymes involved in the catabolism of organophosphorus molecules are of interest in the pharmaceutical and agribiotech industrial sectors.

There has been a range of phosphate starvation and limitation studies in bacteria carried out through cDNA microarrays to investigate global transcriptome changes [10-13] and qualitative overview analysis using 2-DE workflows to study broad proteome changes [14-17]. To date, there have only been two high-throughput quantitative proteomic assays of $\mathrm{P}_{\mathrm{i}}$ limitation in cyanobacteria, focusing on the marine species Prochlorococcus $[18,19]$. While it is tempting to compare the observations obtained from these studies, comparison among datasets has also been further complicated by the different types of experiments conducted, which range from evaluation of the short-term responses to starvation conditions (shift to P-free medium) to studies of adaptation to $\mathrm{P}_{\mathrm{i}}$ limitation. However, one of the most common observations in all of these studies is the up-regulation of pho regulon genes, as seen in studies conducted on Bacillus subtilis [15], Escherichia coli [19], Prochlorococcus spp. [13,18,19], Synechococcus WH8102 [20] and Corynebacterium glutamicum [21].

Unlike other prokaryotic systems, reports on $\mathrm{P}_{\mathrm{i}}$ limitation responses in cyanobacteria are relatively few. When available, these studies consist more generally of shortterm $P_{i}$ shock experiments with a shift from replete to $P_{i}$ free medium [10,13,20,22-26]. However, these studies have revealed that the phosphate-sensing system in Synechocystis is modulated by SphS (sll0337; histidine kinase; analogous to PhoR of E. coli) and SphR (slr0081; response regulator; analogous to PhoB of E. coli) [27], which form a two-component signal transduction system. Also, an in-depth investigation of $\mathrm{P}_{\mathrm{i}}$-binding proteins within Synechocystis showed differential regulation, functional roles and $\mathrm{P}_{\mathrm{i}}$ transport characteristics for its two ABC-type phosphate transporter proteins, PstS1 and PstS2 [22].

Inactivation of phou, one of the genes encoding phosphate-specific transport system regulatory proteins, caused an increase in both inorganic phosphate ( $\mathrm{Pi}$ ) uptake and polyphosphate accumulation rates [27]. It has been shown that under phosphate starvation, the Synechocystis pho regulatory system responds by increasing its transcript abundance by more than 7-fold compared to normal $\mathrm{P}_{\mathrm{i}}$ replete conditions [10]. It has been suggested that high light levels also triggered the pho regulon, since light accelerated phosphate assimilation despite limited cell capacity to perform the task [28]. Suzuki et al. used DNA microarrays to investigate the Synechocystis phosphate starvation response [10] and found that the genes encoding the $\mathrm{ABC}$-type phosphate transporter (sphX, PstS1 and PstS2 clusters) and extracellular nuclease $(n u c H)$ were significantly up-regulated in addition to the alkaline phosphatase $(p h o A)$ gene. The gene encoding a periplasmic binding protein (urtA) was down-regulated. In a separate study under similar conditions, significant up-regulation of the genes for inorganic pyrophosphatase ( $p p a)$ and exopolyphosphatase (ppx) was observed [29].

The goal of this work was to study the adaptation of Synechocystis to phosphate limitation using a quantitative shotgun proteomics workflow [30,31]. The proteomes of Synechocystis grown in different phosphate concentrations (3\% and $0.3 \%$ of the non-limiting level in BG-11 medium) were quantitatively measured using iTRAQ reagents. Coupled with enzyme assays, this investigation forms the basis for understanding global cellular responses, such as the central metabolism and biosynthetic pathways, of Synechocystis in phosphatelimited environments. This study is both novel and timely as it specifically deals with an in-depth analysis of $\mathrm{P}_{\mathrm{i}}$-depletion over different levels of phosphate, and over a longer timescale, than has been explored by others. The results of this study provide insights into the ways in which cellular processes are directly influenced by ambient phosphorus concentrations.

\section{Results and discussion}

\section{Growth characteristics}

In phosphate-depleted conditions, the growth rate of Synechocystis was significantly impaired (Additional file 1: Figure S1), with noticeable reduction of colour within the flasks (data from observation, image not available). The control culture reached an $\mathrm{OD}_{730}$ of 7 at the end of the 60-day cultivation, whereas the phosphate-limited cultures only reached a maximum $\mathrm{OD}_{730}$ of 0.9 (for $3 \%$ $\mathrm{P}_{\mathrm{i}}$ level) and 0.5 (for $0.3 \% \mathrm{P}_{\mathrm{i}}$ level). Their specific growth rates were calculated as 0.20 day $^{-1}$ for the control culture, 0.012 day $^{-1}$ for $3 \% \mathrm{P}_{\mathrm{i}}$ culture and 0.002 day $^{-1}$ for $0.3 \% \mathrm{P}_{\mathrm{i}}$ culture. This impairment in growth with suboptimal $\mathrm{P}_{\mathrm{i}}$ levels was expected, and agrees with the trend observed for other organisms [21,32,33].

\section{Proteome overview}

A total of 120 proteins were identified and quantified with two or more peptides (Additional file 2: Table S1). A quarter of these were associated with central metabolic functions (glycolysis, pentose phosphate pathway, glycogenesis, glyconeogenesis and carbon fixation) (Additional file 1: Figure S2). A significant fraction (19.2\%) was associated with uncharacterised and hypothetical proteins, 
and $21 \%$ were associated with photosynthesis. In the study, 13 detected proteins were more abundant in the $3 \%$ $\mathrm{P}_{\mathrm{i}}$ culture, whereas the abundances of 12 proteins were observed to have increased within the $0.3 \% \mathrm{P}_{\mathrm{i}}$ culture (Table 1). Conversely, we observed 13 proteins to be lowered in abundance within the $3 \% \mathrm{P}_{\mathrm{i}}$ culture, while 16 other identified proteins were less abundant in the $0.3 \% \mathrm{P}_{\mathrm{i}}$ culture (Table 1, Figure 1, Additional file 2: Table S1).

It is instructive to observe that cells acclimated to a lower initial phosphate concentration demonstrate a

Table 1 Differentially abundant proteins related to control cultures

\begin{tabular}{|c|c|c|c|c|c|c|c|c|}
\hline \multicolumn{5}{|c|}{ Protein details } & \multicolumn{4}{|c|}{ Relative abundance } \\
\hline Functional category & ORF & Protein name & $\begin{array}{l}\text { Gene } \\
\text { name }\end{array}$ & $\begin{array}{c}\# \\
\text { peptides }\end{array}$ & $\begin{array}{l}3 \% \\
P_{i}\end{array}$ & SD & $\begin{array}{c}0.3 \% \\
P_{i}\end{array}$ & SD \\
\hline \multirow{4}{*}{$\begin{array}{l}\text { Nutrient assimilation and } \\
\text { regulation }\end{array}$} & sll0654 & Alkaline phosphatase & phoA & 3 & $2.72^{b}$ & 0.09 & $3.74^{\mathrm{b}}$ & 0.28 \\
\hline & sll0680 & Periplasmic Pi-binding protein & pstS1 & 7 & 1.04 & 0.23 & $2.25^{\mathrm{b}}$ & 0.60 \\
\hline & $\operatorname{sir} 1247$ & Periplasmic Pi-binding protein & psts2 & 15 & $2.99^{a}$ & 0.34 & $4.69^{a}$ & 0.15 \\
\hline & $\operatorname{slr} 1622$ & Inorganic pyrophosphatase & ppa & 11 & $1.32^{\mathrm{b}}$ & 0.05 & 1.38 & 0.02 \\
\hline \multirow{13}{*}{$\begin{array}{l}\text { Light harvesting and } \\
\text { photosystems }\end{array}$} & sll1578 & C-phycocyanin alpha chain & $C P C A$ & 169 & $0.67^{\mathrm{a}}$ & 0.06 & $0.28^{\mathrm{a}}$ & 0.03 \\
\hline & sll1577 & C-phycocyanin beta chain & $c p c B$ & 311 & $0.75^{\mathrm{a}}$ & 0.09 & $0.30^{\mathrm{a}}$ & 0.02 \\
\hline & sll1580 & $\begin{array}{l}\text { Phycobilisome } 32.1 \mathrm{kDa} \text { linker polypeptide, phycocyanin- } \\
\text { associated, rod } 1\end{array}$ & $\mathrm{cpcCl}$ & 9 & $0.58^{\mathrm{b}}$ & 0.07 & $0.22^{c}$ & 0.06 \\
\hline & sll1579 & $\begin{array}{l}\text { Phycobilisome } 32.1 \text { kDa linker polypeptide, phycocyanin- } \\
\text { associated, rod } 2\end{array}$ & $c p c C 2$ & 41 & $0.71^{\mathrm{a}}$ & 0.13 & $0.28^{\mathrm{b}}$ & 0.03 \\
\hline & slr2051 & Phycobilisome rod-core linker polypeptide & $c p c G$ & 21 & $0.73^{b}$ & 0.05 & $0.29^{\mathrm{a}}$ & 0.04 \\
\hline & slr2067 & Allophycocyanin alpha chain & $a p c A$ & 85 & $0.56^{\mathrm{a}}$ & 0.03 & $0.33^{\mathrm{a}}$ & 0.01 \\
\hline & slr1986 & Allophycocyanin beta chain & $a p c B$ & 64 & $0.61^{a}$ & 0.01 & $0.42^{\mathrm{a}}$ & 0.02 \\
\hline & sll0928 & Allophycocyanin-B & $a p c D$ & 9 & $0.55^{\mathrm{b}}$ & 0.03 & $0.34^{\mathrm{a}}$ & 0.03 \\
\hline & slr0335 & Phycobilisome LCM core-membrane linker polypeptide & $a p c E$ & 21 & $0.56^{\mathrm{a}}$ & 0.07 & $0.31^{\mathrm{a}}$ & 0.00 \\
\hline & sll0258 & Cytochrome c-550 & $p s b V$ & 27 & 0.88 & 0.04 & $0.55^{\mathrm{a}}$ & 0.04 \\
\hline & $\operatorname{sir} 1643$ & Ferredoxin NADP reductase & petH & 10 & 0.86 & 0.05 & $0.73^{b}$ & 0.07 \\
\hline & slr0729 & Thylakoid-associated protein slr0729 & slr0729 & 21 & $1.39^{\mathrm{b}}$ & 0.12 & 1.28 & 0.04 \\
\hline & ssl2501 & Uncharacterized thylakoid-associated protein ssl2501 & ss/2501 & 7 & $2.97^{\mathrm{a}}$ & 0.04 & $2.82^{\mathrm{a}}$ & 0.29 \\
\hline \multirow[t]{6}{*}{ Central metabolism } & $\operatorname{slr} 1793$ & Transaldolase & tal & 27 & $1.28^{\mathrm{b}}$ & 0.05 & $2.05^{\mathrm{a}}$ & 0.01 \\
\hline & sll0329 & 6-phosphogluconate dehydrogenase, decarboxylating & gnd & 13 & $1.49^{\mathrm{a}}$ & 0.02 & $1.88^{\mathrm{a}}$ & 0.16 \\
\hline & $\operatorname{slr} 1843$ & Glucose-6-phosphate 1-dehydrogenase & $z w f$ & 6 & $1.54^{\mathrm{b}}$ & 0.10 & $1.99^{\mathrm{b}}$ & 0.10 \\
\hline & slr0394 & Phosphoglycerate kinase & $p g k$ & 8 & $0.60^{\mathrm{b}}$ & 0.05 & 0.86 & 0.05 \\
\hline & slr0009 & RuBisCO large subunit & $r b c L$ & 46 & $0.64^{b}$ & 0.02 & $0.64^{b}$ & 0.10 \\
\hline & slr0012 & RuBisCO small subunit & rbcs & 24 & 0.82 & 0.03 & $0.38^{\mathrm{a}}$ & 0.00 \\
\hline \multirow[t]{3}{*}{ Biosynthesis } & slr1994 & 3-oxoacyl-[acyl-carrier-protein] reductase 2 & fabG2 & 5 & $2.17^{\mathrm{b}}$ & 0.01 & $2.83^{\mathrm{a}}$ & 0.05 \\
\hline & sll1852 & Nucleoside diphosphate kinase & $n d k$ & 4 & 1.00 & 0.12 & $2.07^{b}$ & 0.15 \\
\hline & sll1356 & Glycogen phosphorylase & $g \lg P(2)$ & 4 & $1.51^{\mathrm{b}}$ & 0.13 & $2.00^{c}$ & 0.17 \\
\hline \multirow{6}{*}{$\begin{array}{l}\text { Transcription, translation and } \\
\text { stress }\end{array}$} & sll0020 & ATP-dependent Clp protease regulatory subunit & $c l p C$ & 7 & 0.71 & 0.08 & $0.72^{\mathrm{b}}$ & 0.03 \\
\hline & slr2076 & groEL protein 1 & groLl & 17 & $1.36^{\mathrm{b}}$ & 0.04 & 0.83 & 0.61 \\
\hline & sll1099 & Elongation factor Tu & tuf & 34 & 0.86 & 0.17 & $0.74^{\mathrm{a}}$ & 0.10 \\
\hline & sll1712 & DNA-binding protein $\mathrm{HU}$ & hup & 6 & 0.75 & 0.13 & $0.50^{\mathrm{b}}$ & 0.11 \\
\hline & $\operatorname{slr} 1198$ & Rehydrin & rehydrin & 14 & $1.57^{\mathrm{a}}$ & 0.08 & 1.55 & 0.31 \\
\hline & $\operatorname{slr1516}$ & Superoxide dismutase [Fe] & $\operatorname{sod} B$ & 31 & 1.67 & 0.62 & $2.46^{\mathrm{a}}$ & 0.18 \\
\hline \multirow[t]{3}{*}{ Hypotheticals } & slr0645 & Slr0645 protein & slr0645 & 4 & 1.23 & 0.31 & $2.42^{\mathrm{b}}$ & 0.32 \\
\hline & $\operatorname{sir} 1619$ & Slr1619 protein & $\operatorname{sir} 1619$ & 2 & 0.68 & 0.05 & $0.39^{b}$ & 0.09 \\
\hline & slr2025 & Slr2025 protein & slr2025 & 23 & $1.29^{\mathrm{b}}$ & 0.06 & 1.26 & 0.05 \\
\hline
\end{tabular}




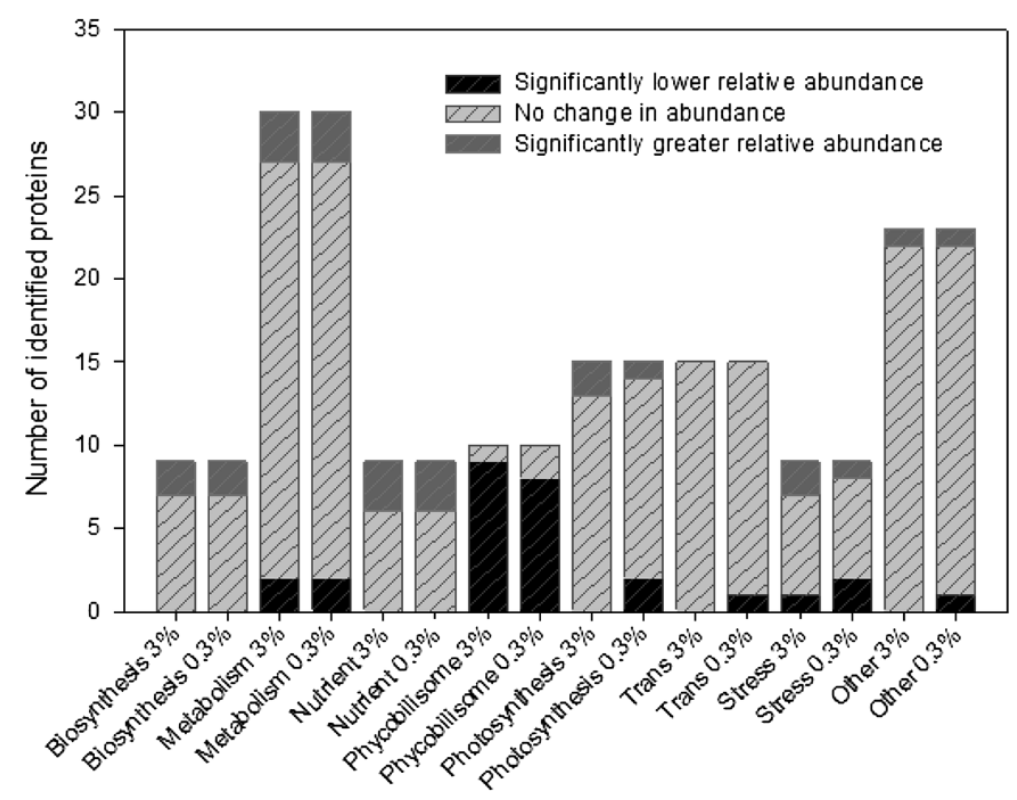

Figure 1 Stacked bar chart highlighting the proportion of differentially abundant proteins found within $3 \%$ and $0.3 \% P_{i}$ cultures.

significantly higher fraction of differentially more abundant proteins from almost all categories (Figure 1), with the exception of proteins associated with the phycobilisomes. These differences suggest a substantial physiological shift within cells in order to maximise $P_{i}$ usage throughout. Indeed, when observing relative abundance levels, the functional categories most broadly affected are metabolism, nutrient acquisition and the proteins of the phycobilisomes (Figure 1, Table 1).

\section{Nutrient assimilation and regulation}

The most commonly reported response to phosphate limitation is an increase in the activity of the periplasmic enzyme alkaline phosphatase [34]. In this study, the alkaline phosphatase activity was observed to increase as the phosphate level decreased, reaching a maximum activity of $60.7 \mathrm{nmol} / \mathrm{min} \cdot \mathrm{mg}$ in the $0.3 \% \mathrm{P}_{\mathrm{i}}$ culture (Figure 2, Table 2). No alkaline phosphatase activity was detected in the control culture. This finding corresponds well with alkaline phosphatase activity changes observed in other cyanobacteria (Plectonema boryanum [35] and Aphanizomenon ovalisporum [36]) subjected to longterm phosphate limitation. No acid phosphatase activity was detected in either of the $P_{i}$-limited cultures by our methods.

Ten proteins involved with nutrient acquisition and regulation (Figure 2A) were quantified. Of these, six of the eight proteins associated with phosphate assimilation and storage were significantly more abundant than in the control (Figure 2A, Table 1). The alkaline
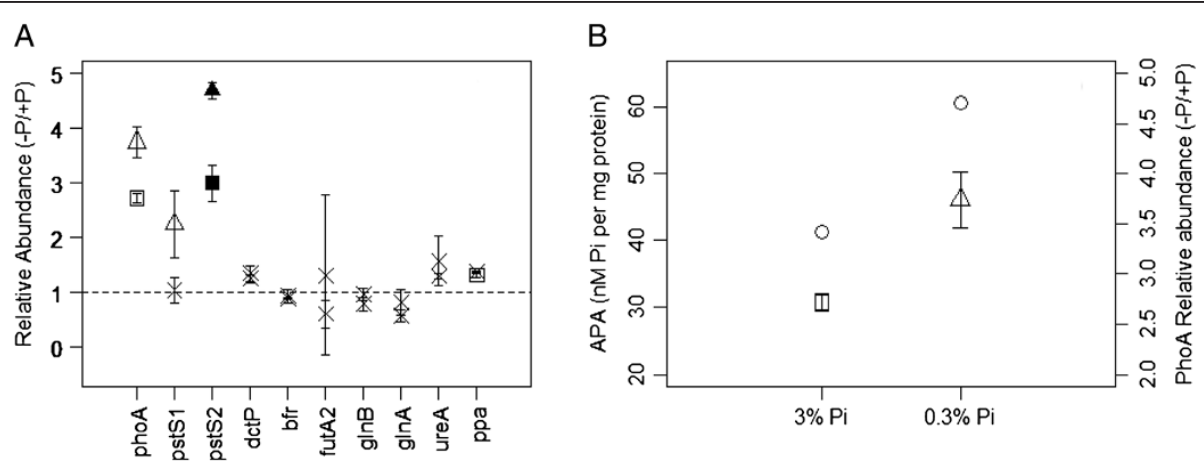

Figure 2 Nutrient assimilation and regulation. (A) Relative abundances of proteins involved in nutrient acquisition. Non-significant observations are marked with a cross. Cultures grown in $3 \% \mathrm{P}_{\mathrm{i}}$ are indicated with a square, whilst $0.3 \%$ cultures are indicated with a triangle. Empty datum points correspond to significant observations without a Bonferonni correction applied, whereas filled points are observations with the correction. The dotted line represents parity in abundance between control and experimental cultures. (B) Levels of measured APase activity (circles) and relative abundances of PhoA within cultures grown in 3\% and $0.3 \% \mathrm{P}_{\mathrm{i}}$. 
Table 2 Alkaline phosphatase activity within samples

\begin{tabular}{ccccc}
\hline $\begin{array}{c}\text { Phosphate } \\
\text { level }\end{array}$ & $\begin{array}{c}\text { Phosphate concentration } \\
(\mathbf{m g} / \mathbf{L})\end{array}$ & $\begin{array}{c}\text { APA (nmoles of Pi released per min per } \mathbf{m g} \text { of } \\
\text { protein) }\end{array}$ & $\begin{array}{c}\text { PhoA relative } \\
\text { abundance }\end{array}$ & $\begin{array}{c}\text { PhoA standard } \\
\text { deviation }\end{array}$ \\
\hline $\mathbf{1 0 0 \%}$ & 40 & 0 & na & na \\
$\mathbf{3} \%$ & 1.2 & 41.3 & 2.72 & 0.09 \\
$\mathbf{0 . 3 \%}$ & 0.12 & 60.7 & 3.74 & 0.28 \\
\hline
\end{tabular}

The phosphate concentration in the samples was determined using the acid molybdate method [37], and p-nitrophenylphosphate as substrate. Only alkaline phosphatase activity was detected.

phosphatase enzyme, PhoA, and the periplasmic phosphate-binding protein, PstS2, were both significantly more abundant in both $3 \%$ and $0.3 \%$ Pi cultures, whereas inorganic pyrophosphatase (ppa) was significantly more abundant in 3\% Pi culture. We have further confidence with PstS2 abundances, as both data points were significant using the Bonferroni correction. As would be expected, there appears to be no significant observations regarding proteins involved with carbon sources (DctP), iron (bfr) and nitrogen metabolism (GlnA, GlnB, and UreA).

Considering both the relative protein abundance of PhoA in the $100 \%, 3 \%$ and $0.3 \% \mathrm{P}_{\mathrm{i}}$ cultures, and observed APase activity (Figure 2B, Table 2), there is a direct correlation $(\mathrm{p}<0.05$, where polynomial regressions fitted both datasets with $\mathrm{R}^{2}$ values $>0.99$, and APase activity is approximately $22.5 \mathrm{x}$ PhoA abundance). To the authors' knowledge, this is the first observed direct correlation between protein abundances and APase activity within Synechocystis.

An interesting observation in relative levels of protein abundances are the significant differences between abundances of proteins in the $3 \% \mathrm{P}_{\mathrm{i}}$ and $0.3 \% \mathrm{Pi}$ cultures. PhoA, and PstS12 are both significantly more abundant in the $0.3 \% \mathrm{P}_{\mathrm{i}}$ than in $3 \% \mathrm{P}_{\mathrm{i}}$ (Figure 2A), whereas there is no significant difference in abundance of Ppa proteins between the two cultures. This suggests the possibility of a two-tier strategy in cell acclimation: (i) a phased response, whereby protein abundance is putatively associated with/ proportional to internal or external phosphate concentrations, and (ii) a switched response, whereby the cell has a possible biochemical 'marker' for activation, for example an as yet undefined external phosphate concentration, and which below this abundance levels of that protein are constitutively maintained within the cell. However, more research is required to investigate this.

It has been previously demonstrated that the two periplasmic phosphate-binding proteins PstS12 have unique enzymatic and regulatory properties [22]. pstS1 encodes a low-affinity, high velocity $\mathrm{P}_{\mathrm{i}}$ transporter protein that was expressed to a significantly greater extent than the pstS2 transcript when cells were grown in $\mathrm{P}_{\mathrm{i}}$-replete conditions. However, pstS2, a high-affinity, lowvelocity transporter, was expressed at significantly higher levels under $\mathrm{P}_{\mathrm{i}}$-stress conditions [22]. In addition, the disruption of pstS1 caused constitutive expression of the pho regulon, indicating a role in external $P_{i}$ sensing [22]. The results here, in part, support those findings. However, our results also infer that elevated expression of pstS2 is not limited to a stress response, but is also an acclimation response. PstS2 is significantly higher than PstS1 within $3 \%$ and $0.3 \% \mathrm{P}_{\mathrm{i}}$ cultures, and the abundance of PstS2 within the $0.3 \% \mathrm{P}_{\mathrm{i}}$ culture is significantly higher than in the $3 \% \mathrm{P}_{\mathrm{i}}$ culture (Figure $2 \mathrm{~A}$ ).

\section{Light harvesting and photosystems}

Light harvesting within Synechocystis is accomplished through large multi-protein complexes, called phycobilisomes, consisting of phycobiliproteins (PBPs). Phycobilisomes are composed of a core complex surrounded by a tiered array of pigmented allophycocyanins, phycocyanins and non-pigmented linker peptides that harness and siphon the light energy to PSII [37]. These structures are significantly affected by prolonged exposure to low $\mathrm{P}_{\mathrm{i}}$ levels in the medium (Figure 3A, Table 1). Within cyanobacteria, phycobilisome loss varies between species, and specifically under different nutrient deprived conditions. For example, a significant reduction of cyanobacterial phycobilisome content, known as chlorosis, is well known during nitrogen deprivation [38,39], and yet a recent proteomic study of Synechocystis during $\mathrm{CO}_{2}$ limitation showed a minimal decrease in phycobiliprotein abundance [40]. However, that result is in contrast to previous transcriptome experiments [41,42]. Nevertheless, a study of Synechococcus levels of bleaching varied significantly between growth in nitrogen, sulphur and phosphorus deficient media, possibly reflecting differentially regulated subprocesses [43]. Interestingly, Wegener et al., [44] demonstrated that, after 6 days of $\mathrm{P}_{\mathrm{i}}$ depletion, phycobilisomes and pigment biosynthesis were unaffected, yet their cells demonstrated significant chlorosis. This is unexpected and in contrast to our results, in which significant reduction of phycobilisome structures corresponded with chlorosis. It is difficult to immediately explain this disparity; however, the difference in timescales between both experiments may hold a clue.

It is interesting to note the significantly linear relationship within the phycocyanin group and allophycocyanin 

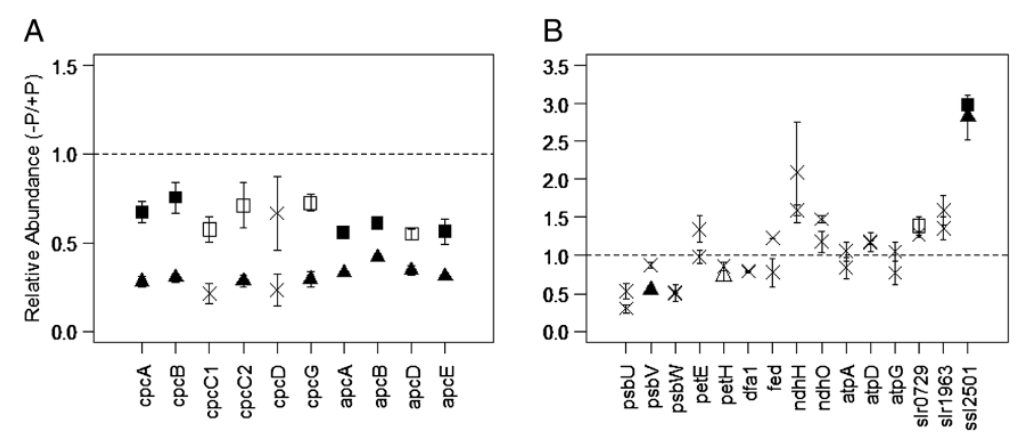

Figure 3 Protein abundances involved with photosynthesis. (A) Relative abundances of phycobilisome proteins, and (B) proteins of the photosystems, PETC, and other thylakoid-related proteins. Non-significant observations are marked with a cross. Cultures grown in $3 \% \mathrm{P}_{\mathrm{i}}$ are indicated with a square, whilst $0.3 \%$ cultures are indicated with a triangle. Empty datum points correspond to significant observations without a Bonferonni correction applied, whereas filled points are observations with the correction. The dotted line represents parity in abundance between control and experimental cultures.

group of proteins. A statistical analysis of the phycobiliprotein abundances between the $3 \%$ and $0.3 \% \mathrm{P}_{\mathrm{i}}$ cultures revealed that there is no significant difference between the phycocyanins (CpcA-G, Figure 3A) and the allophycocyanins (ApcA-E, Figure $3 \mathrm{~A}$ ) at the $3 \% \mathrm{P}_{\mathrm{i}}$ level $(\mathrm{p}=0.09, \mathrm{df}=32)$. However, there is a significant difference at the $0.3 \% \mathrm{P}_{\mathrm{i}}$ level $(\mathrm{p}=0.006, \mathrm{df}=32)$. This difference indicates that the light harvesting antennae of $0.3 \%$ $P_{i}$ culture cultures have significantly less of the phycocyanins in proportion to their allophycocyanin content than do the $3 \% \mathrm{P}_{\mathrm{i}}$ culture cultures. This potentially suggests independent regulatory systems between the different PBP groups, or differential regulation of group specific proteases, whose activity is putatively dependent upon external $P_{i}$ concentrations. This is a reasonable hypothesis, as phycocyanins are attached externally to allophycocyanins through linker peptides, and light energy is funnelled from phycocyanins through allophycocyanins to PSII [37]. This regulation may be due to the organism attempting to reduce photosynthetically induced oxidative damage.

Four proteins within photosystem II (PSII) and the photosynthetic electron transport chain (PETC) are differentially less abundant (Figure 3B). Both PsbU and PsbW appear to be less abundant than in the control culture under both conditions, whereas PsbV is significantly less abundant only in the $0.3 \% \mathrm{P}_{\mathrm{i}}$ culture. The extrinsic protein PsbV, alongside PsbU, is a critical protein in the oxygen evolving complex of cyanobacterial PSII complexes $[45,46]$. Indeed, PsbU appears to promote stability within the water-splitting PSII structure [47]. PsbW (characterized recently, and more commonly referred to as Psb28 within Synechocystis [48]) appears to be closely associated with PSII complexes, and more specifically to the biogenesis of the chlorophyll-binding CP47 protein [49]. As a consequence, it appears that when cells acclimate to low levels of ambient $\mathrm{P}_{\mathrm{i}}$, light harvesting and structural integrity of the PSII assembly is compromised.

Ferridoxin NAPDH reductase (PetH, Figure 3B) is commonly associated with PSI and the terminal end of the PETC, nominally with regards to the production of reducing energy. However, in Synechocystis it has also been demonstrated to be closely associated with the phycobilisomes [50]. Within our study, the relative abundance of PetH is significantly less within the $0.3 \% \mathrm{P}_{\mathrm{i}}$ culture, but not the $3 \% \mathrm{P}_{\mathrm{i}}$. This then, coupled with the PsbV observation, implies a strategic down regulation of PETC and PSII activity as ambient $\mathrm{P}_{\mathrm{i}}$ concentrations decrease. However, no other proteins associated with PSI were identified, and the suggestion that PSI function was decreased requires further validation in the future.

It is clear that ambient $P_{i}$ concentrations have a significant effect upon the photosynthetic machinery within Synechocystis. However, it is also clear that this did not mean a complete loss of function, as occurs during prolonged nitrogen deprivation [38], and represents a proportional loss of function, dependent upon $\mathrm{P}_{\mathrm{i}}$ concentrations. Our results present evidence of a response comparable to Synechococcus sp. PCC 7942 [43].

\section{Central metabolism}

The central metabolism of Synechocystis was affected by prolonged exposure and acclimation to reduced $P_{i}$ concentrations. Ten proteins were identified as being significantly differentially abundant in both $3 \% \mathrm{P}_{\mathrm{i}}$ and $0.3 \% \mathrm{P}_{\mathrm{i}}$ compared to the control cultures (Figure 4A, Table 1). Three proteins that were more abundant than the control (in both\% $\mathrm{P}_{\mathrm{i}}$ and $0.3 \% \mathrm{P}_{\mathrm{i}}$ cultures) were transaldolase (Tal), 6-phosphogluconate dehydrogenase (decarboxylating) (Gnd) and glucose-6-phosphate 1dehydrogenase (Zwf) (Figure 4A). These proteins function within the $6^{\text {th }}, 3^{\text {rd }}$ and $1^{\text {st }}$ steps in the pentose phosphate pathway (PPP) respectively. Allied to this, 

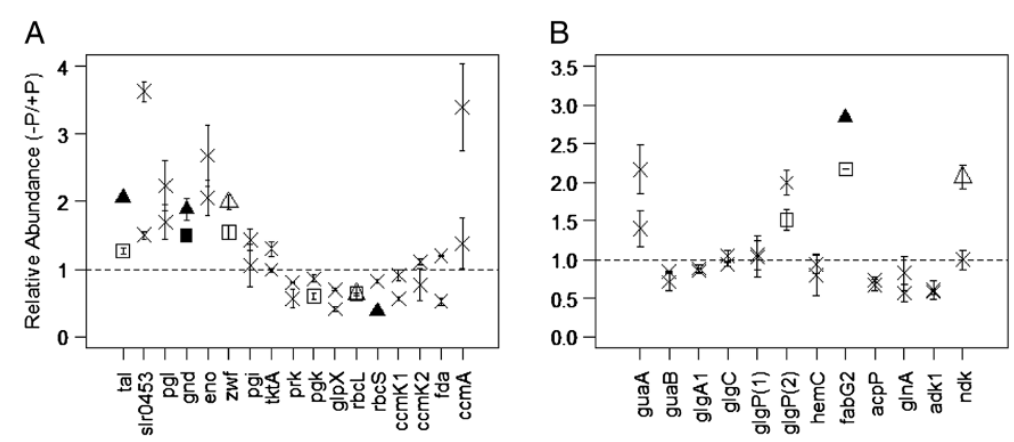

Figure 4 Relative abundances of proteins involved in (A) central metabolic processes, and (B) biosynthesis. Non-significant observations are marked with a cross. Cultures grown in $3 \% \mathrm{P}_{\mathrm{i}}$ are indicated with a square, whilst $0.3 \%$ cultures are indicated with a triangle. Empty datum points correspond to significant observations without a Bonferonni correction applied, whereas filled points are observations with the correction. The dotted line represents parity in abundance between control and experimental cultures.

6-phosphogluconolactonase (Pgl), the $2^{\text {nd }}$ step in PPP, demonstrated a strong indication that it was more abundant in both the $3 \%$ and the $0.3 \%$ cultures (Figure $4 \mathrm{~A}$ ), but this is not clear. This is an important observation, as the PPP acts to generate reducing energy (in the form of $\mathrm{NADPH}$ ), and also generates metabolic precursors for nucleotide/nucleic acid and amino acid biosynthesis [51].

In contrast, three glycolysis and carbon fixation proteins, phosphoglycerate kinase (Pgk) and the two subunits of rubisco (RbcL and $\mathrm{RbcS}$ ) were significantly less abundant in $3 \% \mathrm{P}_{\mathrm{i}}$ and $0.3 \% \mathrm{P}_{\mathrm{i}}$ vs the $100 \% \mathrm{P}_{\mathrm{i}}$ controls (Figure 4A, Table 1). These proteins are the central enzymes within the first two phases of the Calvin-Benson cycle (being the fixation of $\mathrm{CO}_{2}$, the reduction of 3-phosphoglycerate, and the regeneration of ribulose 1,5-bisphosphate). This cycle is critical in all photosynthetic organisms, and is fundamentally limiting to growth and reproduction. This result is unsurprising, given the significant reduction in photosynthetic light harvesting earlier observed in both $3 \%$ and $0.3 \% \mathrm{P}_{\mathrm{i}}$ cultures. It is also interesting to note that the enzyme Transketolase (TktA), which functions in both the Calvin-Benson cycle and PPP was not differentially abundant.

Interestingly, at the transcript level, gnd, tal and $z w f$ were all strongly induced under nitrogen deprivation, as well as one of the two glycogen phosphorylases $g l p P$ (sll1367). The Calvin-Benson cycle genes $r b c L$ and $r b c S$ were also down regulated [52]. Our results demonstrate that the other glycogen phosphorylase (sll1356), rather than sll1367 is more abundant (see below), however the similarity in results is noteworthy. Osani and co-workers [52] concluded that nitrogen deprivation induces sugar catabolism, and that the PPP is the primary method of reducing power production. Our results confirm that $\mathrm{P}_{\mathrm{i}}$ deprivation also leads to a similar biochemical response, and thus indicate that the central metabolic response of the cell is similar for both $\mathrm{N}$ and $\mathrm{P}_{\mathrm{i}}$ deprivation.
However this response has a significantly different level of severity depending upon $\mathrm{N}$ or $\mathrm{P}_{\mathrm{i}}$ deprivation [43].

When considering energy metabolism (defined in this instance as the synthesis and degradation of the glycolytic/ PPP precursor glucose 6-phosphate), Figure 4B shows a significant difference between the relative abundance of two glycogen phosphorylation proteins (GlgP(1) \& GlgP (2)). Both proteins are assumed to function to degrade glycogen, thereby generating D-glucose-1-phosphate in the preparatory, rate-limiting step before entry into glycolysis. However, the differential relative abundance between both proteins suggests differential functional roles within the cell. The enhancement of central PPP protein abundances highlighted earlier suggests that glycogen is being processed by $\operatorname{GlgP}(2)$ to support the production of $\mathrm{NADPH}$ and pentose sugars. As mentioned earlier, GlgP (1) rather than $\mathrm{GlgP}(2)$ was found to be differentially upregulated at the transcript level when subjected to $\mathrm{N}$ deprivation [52], which then suggests differing regulatory controls for each enzyme and condition. Also, Wegener and associates observed that sll1367 was more abundant than sll1356 under P deplete conditions [44], and so we must conclude that over short P starvation periods, sll1367 is preferred, and over longer, chronic, periods sll1356 predominates.

\section{Transcription, translation, stress and hypothetical proteins}

Six proteins out of 24 relating to transcription, translation and stress were significantly differentially abundant within both reduced $P_{i}$ cultures. An interesting group of proteins are the ATP-dependant Clp proteases, ClpC, ClpP1, ClpP2 and ClpB. These proteins are vital for growth and stress acclimation, and act to degrade denatured polypeptides and maintain cellular homeostasis [53]. Within Escherichia coli there is evidence that these proteins act in a multi-subunit complex, with the exclusion of ClpB (which acts independently) [54]. 
However, little is known about cyanobacterial Clp proteases, except that cyanobacterial $\mathrm{ClpC}$ is $90 \%$ similar to the $\mathrm{ClpC}$ in plant chloroplasts, is transcriptionally constitutively expressed at a level which appears to be unaffected by stress conditions, and that loss-of-function manipulation is generally fatal [55]. This last point emphasises the protein's role as an essential chaperone.

As such, it is interesting that the regulatory subunit, ClpC, was significantly lower in both reduced $P_{i}$ cultures, and yet one of the two identified isomeric forms of ClpP, ClpP1, demonstrated no significant differential abundance (Figure 5). While this seems counterintuitive, later studies showed that $\mathrm{ClpC}$ does not interact with $\mathrm{ClpP} 1$ or $\mathrm{ClpP} 2$, but rather with ClpP3 and ClpP4. As such, two distinct and separate Clp protease complexes function within Synechococcus elongates PCC 7942 [56], which indicates that each complex functions to degrade differing substrates. At this time, the substrate for $\mathrm{ClpC}$ is unknown. Considering the other chaperone proteins identified, only GroL1 was differentially abundant (Figure 5). This has been observed within Prochlorococcus marinus MED4 during high-light stress [57], but was not observed within MED4 during acclimation to low $\mathrm{P}_{\mathrm{i}}$ [18]. This abundance difference between species and environmental conditions is puzzling, and likely reflects other, unknown, contributory factors.

Translation appears to be affected as the elongation factor, EF-Tu (Tuf, Figure 5), which facilitates the entry of aminoacyl tRNA into the free site of the ribosome, was significantly lower in abundance within the $0.3 \%$ culture. EF-Tu is critical in successful translation, and acts as a powerful indicator that translation is lower within cells acclimated to long term $\mathrm{P}_{\mathrm{i}}$ deprivation. It is instructive to note that the other three elongation factors identified in our study (Gst, Tsf, and FusA) were unaffected, which may indicate a regulatory role for EF-Tu.
Two known stress response proteins were more abundant in low $\mathrm{P}_{\mathrm{i}}$ : rehydrin and SodB (Figure 5). The functional role of rehydrin, a protein associated with desiccation stress in mosses [58], is unknown, and this represents the first recording of this protein being intrinsic to $P_{i}$ acclimation. In contrast, the function of the iron superoxide dismutase protein, SodB, is well characterised [59], and is primarily responsible for the cell's response to oxidative stress.

One biosynthetic protein was significantly differentially abundant within the $\mathrm{P}_{\mathrm{i}}$-deplete cultures than the control, 3-oxoacyl-[acyl-carrier protein] reductase (FabG2, Figure 4B, Table 1), which participates in fatty acid biosynthesis. This is interesting as fatty acids play two main functions within the cell: (i) they are precursors of membrane lipids, and (ii) they accumulate for energy storage. However given their differential abundance, it would be expected that another critical protein required in this process, the acyl-carrier protein (acp) demonstrates no differential abundance in either the $3 \% \mathrm{P}_{\mathrm{i}}$, or the $0.3 \% \mathrm{P}_{\mathrm{i}}$ culture. The reason for this is unclear, however the abundance of FabG2 is a strong indication that the cell over produced fatty acids when acclimating to low $P_{i}$ environments. Indeed, fatty acids have been speculated to have a role in stress tolerance within cyanobacteria, notably to desiccation, salt and temperature stress (see Singh et al. [60] for review). As well as energy storage, the production of lipids may help to stabilize nutrient acquisition machinery within the external membrane [60], and replace lipids damaged by reactive oxygen species, which have concurrent effects upon membrane fluidity and other cellular metabolic functions [61]. The role of fatty acids in desiccation stress is intriguing, specifically due to the increased abundance of the protein rehydrin within the $3 \%$ culture (Figure 5, Table 1).

Twenty-one hypothetical proteins were identified within this study (Additional file 2: Table S1). Although at the time of writing, the functions of particular

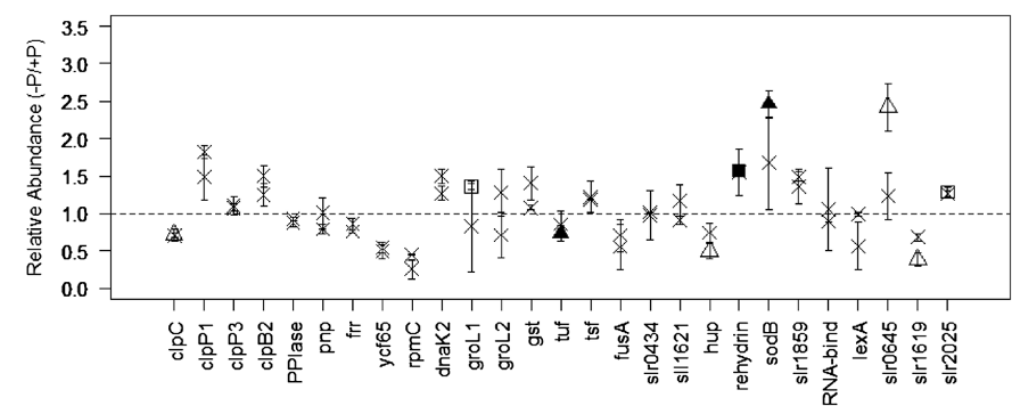

Figure 5 Relative abundances of proteins involved with transcription, translation, stress and uncharacterised hypothetical proteins. Non-significant observations are marked with a cross. Cultures grown in $3 \% \mathrm{P}_{\mathrm{i}}$ are indicated with a square, whilst $0.3 \%$ cultures are indicated with a triangle. Empty datum points correspond to significant observations without a Bonferonni correction applied, whereas filled points are observations with the correction. The dotted line represents parity in abundance between control and experimental cultures. 
hypothetical proteins are unknown, it is an important observation that three proteins are differentially abundant within the cultures within this study. They are slr0645, slr1619 and slr2025 (Figure 5, Table 1). Of the three, slr2025 was recently observed within a proteomewide survey of Synechocystis under $\mathrm{CO}_{2}$ limitation. However, it was not considered differentially abundant [42], and so appears to be unimportant to acclimation to that environment. In our study, it was more abundant within the $3 \% \mathrm{P}_{\mathrm{i}}$ culture.

\section{Conclusions}

Since Synechocystis typically inhabit rivers and lakes where the ambient $P_{i}$ concentrations range from nanomolar to micromolar ranges [62], our control cultures were acclimated to "luxury" $\mathrm{P}_{\mathrm{i}}$ concentrations, and hence the $3 \%$ and the $0.3 \% \mathrm{P}_{\mathrm{i}}$ cultures, once re-acclimated, are more indicative of natural conditions. This study then emphasises the physiological mechanisms important for normal cellular reproduction and growth. The observed proteome acclimation response to environmental phosphate concentrations involved shifts in cellular abundances of $\mathrm{P}_{\mathrm{i}}$ acquisition and storage mechanisms, coinciding with changes in its photosynthetic machinery and a shift in central metabolism towards the production of reducing energy. While the coordination and control of this response was not uncovered, we and others have previously speculated that it is likely to be a complex interaction of internal regulatory systems initiated through the phoBR homologue of Synechocystis - the SphS-SphR two component system [10], and the activity of PstS1 [22].

We have shown that the observed abundance response of alkaline phosphatase is proportional to measured APase activity, and interestingly that there appears to be a coordinated and specific reduction of individual phycobiliprotein groups during acclimation. As has been previously reported for higher plants, these results provide some evidence that intracellular $\mathrm{P}_{\mathrm{i}}$ concentrations control photosynthetic activity in Synechocystis through the activation or deactivation of $\mathrm{RuBisCO}$ at different concentrations [63]. The similarity of the Synechocystis response to $P_{i}$ deprivation appears to be remarkably similar to prolonged nitrogen deprivation, although the magnitude of the response is greater in low nitrogen than in low $\mathrm{P}_{\mathrm{i}}$. In both cases, the photosynthetic machinery was reduced significantly, and central metabolic processes shift to produce not just reducing energy but nucleotide sugars. We hypothesise that this cellular shift is designed to function in two ways: 1) that an increase in reducing energy provides the 'power' for the cell to stabilize and maintain the cell membranes, and 2) nucleotide sugars can be readily used as precursors for both ATP and GTP, as well as enabling the cell to quickly respond to changes in the environment through rapid production of RNA. The cell is therefore able to respond, grow and replicate rapidly.

\section{Materials and methods Growth conditions}

Synechocystis was principally grown in BG-11 medium [64] in $1 \mathrm{~L}$ conical flasks with a 0.5 -L working volume shaken at $100 \mathrm{rpm}$. The $\mathrm{P}_{\mathrm{i}}$ replete $\mathrm{BG}-11$ medium contained $40 \mathrm{mg} / \mathrm{L}$ of $\mathrm{K}_{2} \mathrm{HPO}_{4}$. For phosphate depletion experiments, the concentration of $\mathrm{K}_{2} \mathrm{HPO}_{4}$ within BG11 was prepared as $3 \% \mathrm{w} / \mathrm{v}(1.2 \mathrm{mg} / \mathrm{L})$ and $0.3 \% \mathrm{w} / \mathrm{v}$ of the control $\mathrm{P}_{\mathrm{i}}$ replete BG-11 medium. The experimental design utilised biological duplicates of Synechocystis PCC 6803 cultured in each condition: (A) 100\% $\mathrm{P}_{\mathrm{i}}$ (control), (B) $3 \% \mathrm{P}_{\mathrm{i}}$, and (C) $0.3 \% \mathrm{P}_{\mathrm{i}}$. Inocula for each culture were prepared by initial centrifugation of stock cultures followed by washing cells twice with sterilized deionised water and once with the respective $P_{i}$ reduced medium, prior to resuspension into the respective medium and experimental inception. Cultures were incubated in a Sanyo MLR-350H environmental chamber at $25^{\circ} \mathrm{C}$ on a 12-h light-dark cycle for 60 days with an initial optical density of 0.2 . Irradiance was provided by cool-white fluorescent lamps at an incident intensity of $70 \mu \mathrm{E} \mathrm{m}^{-2} \mathrm{~s}^{-1}$ as measured by a three-dimensional QSL-2100 Light Sensor (Biospherical Instrument Inc, San Diego, CA). The growth rate was monitored and recorded using an Ultraspec 2100-Pro spectrophotometer (Biochrom, Cambridge, UK) at an OD of $730 \mathrm{~nm}$.

\section{Protein extraction and quantitation}

Cells were harvested at day 60 by centrifugation at $5,000 \times \mathrm{g}$ for $5 \mathrm{~min}$ at $4^{\circ} \mathrm{C}$. The cell pellets were resuspended in $500 \mathrm{mM}$ triethylammonium bicarbonate buffer (TEAB) at $\mathrm{pH} 8.5$ and proteins were extracted through mechanical cracking with liquid nitrogen [65]. Soluble proteins were recovered from the supernatant by centrifugation at $21,000 \times \mathrm{g}$ for $30 \mathrm{~min}$ at $4^{\circ} \mathrm{C}$. The total soluble protein concentrate was then measured using the RC DC Protein Quantification Assay (Bio-Rad, Hertfordshire, UK) according to the manufacturer's protocol.

\section{Acid/alkaline phosphatase assays}

A subsample of cells broken by mechanical grinding with liquid nitrogen as described above was subsequently re-suspended in Tris- $\mathrm{HCl}$ buffer ( $\mathrm{pH}$ 8.0) containing $5 \mathrm{mM} \mathrm{MgCl}$. Alkaline phosphatase assays were performed in duplicate as described by O'Loughlin et al. [66] at $30^{\circ} \mathrm{C}$. The assay solution contained $50 \mathrm{mM}$ Tris- $\mathrm{HCl}(\mathrm{pH} 8.0), 20 \mathrm{mM} \mathrm{MgCl}_{2}$, and $5 \mathrm{mM}$ pnitrophenyl phosphate with 0.01-0.1 mg cell-extract protein in a final reaction volume of $1 \mathrm{~mL}$. For acid 
phosphatase assays, the Tris- $\mathrm{HCl}$ buffer was replaced with $50 \mathrm{mM}$ succinate- $\mathrm{NaOH}$ buffer ( $\mathrm{pH}$ 5.0).

Due to the presence of large quantities of chlorophylls in the cell-extract, detection of p-nitrophenol production by means of the widely used absorbance measurement at $412 \mathrm{~nm}$ was not possible. Reactions were therefore quenched with $0.2 \mathrm{vol}$ of $3 \mathrm{M}$ trichloroacetic acid solution following addition of cell extract protein and a duplicate reaction tube quenched $10 \mathrm{~min}$ later. The resultant reaction supernatants were cooled on ice for $10 \mathrm{~min}$ prior to centrifugation at $20,000 \times \mathrm{g}$ for $5 \mathrm{~min}$ to remove precipitated protein, following which the phosphate concentration in the samples was determined using the acid molybdate method of Fiske and SubbaRow [67]. 'No substrate' and 'no cell-extract' controls were included and activity was expressed as nmol of $P_{i}$ released per min per mg of cell-extract protein, taking the control reactions into account.

\section{SCX prefractionation and iTRAQ}

Approximately $100 \mu \mathrm{g}$ of protein from each sample was placed in PCR clean LoBind microcentrifuge tubes (Eppendorf, Cambridgeshire, UK), then reduced, alkylated and digested as previously reported [18]. The resultant peptide digests were then labelled using 6 labels from an 8-plex iTRAQ chemical reagents kit (AB Sciex UK Limited, UK), with phosphate replete control samples (nominated as $100 \% \mathrm{P}_{\mathrm{i}}$ ) tagged with the 113 and 114 labels, cells grown in $3 \% \mathrm{P}_{\mathrm{i}}$ tagged with 115 and 116, and the $0.3 \%$ phosphate-grown cells tagged with the 117 and 118 labels. Primary peptide fractionation was carried out through strong cation exchange (SCX) on a BioLC HPLC unit (Dionex, Surrey, UK) with a Poly SULFOETHYL A ${ }^{\mathrm{TM}}$ column (PolyLC, Columbia, MD, USA). The column used $5 \mu \mathrm{m}$ particle size, and had dimensions of $200 \mathrm{~mm}$ length with an internal diameter of $2.1 \mathrm{~mm}$ and a $200 \AA$ pore

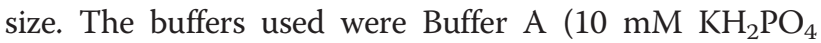
with 20\% HPLC grade acetonitrile (ACN) at $\mathrm{pH} 2.5)$ and Buffer B (10 mM KH $\mathrm{PO}_{4}$ with 20\% HPLC grade acetonitrile (ACN) and $500 \mathrm{mM} \mathrm{KCl}$ at $\mathrm{pH} 3$ ) with a gradient of $0 \%$ B for $5 \mathrm{~min}, 0-40 \%$ B for $30 \mathrm{~min}, 40-100 \%$ B for $10 \mathrm{~min}, 100 \% \mathrm{~B}$ for $5 \mathrm{~min}$, and $0 \% \mathrm{~B}$ for $5 \mathrm{~min}$. Before fractionation, the digests were dried in a vacuum centrifuge and resuspended in $200 \mu \mathrm{L}$ Buffer A. In order to remove salts and unbound iTRAQ reagents, samples were injected onto the column, and manual acquisition was initiated. This allowed Buffer A to flow through the column, leaving bound peptides attached and purging all non-bound material. Two injections were completed before initiation of the gradient. The flow rate was maintained at $200 \mu \mathrm{L} \mathrm{min}{ }^{-1}$. A UV detector (UVD170U) was used to monitor the fractionation process, and the entire operation was controlled and through Chromeleon software (Dionex/LC packings, the Netherlands). Fractions were collected each minute for the duration of the run with a Foxy Jr. Fraction Collector (Dionex). Fractions were selected for subsequent MS/MS analysis according to SCX chromatogram intensity.

Mass spectrometric analysis was performed on a QStar XL Hybrid ESI Quadrupole time-of-flight tandem mass spectrometer, ESI-qQ-TOF MS/MS (Applied Biosystems, Framingham, MA; MDS-Sciex, Concord, Ontario, Canada), coupled with an Ultimate 3000 online capillary liquid chromatography (LC) system (Applied Biosystems, Framingham, MA), with a PepMap C-18 RP column (LC Packings) set to a constant flow rate of $0.3 \mu \mathrm{L} \mathrm{min}$. Selected fractions were dried and resuspended in $10 \mu \mathrm{L}$ of Buffer A prior to analysis. To prevent salts, and other contaminants entering the mass spectrometer, a C-18 column clean up (The Nest Group, Inc. Southborough, MA) of each fraction was performed. Cleaned samples were then injected into the online nanoflow LC-MS/MS unit where the buffers were Buffer A (3\% (v/v) ACN with 0.1\% (v/v) formic acid (FA)), and Buffer B (97\% (v/v) ACN with $0.1 \%(\mathrm{v} / \mathrm{v})$ FA). The gradient applied for the second dimension of chromatography was $3 \%$ Buffer B for 3 min, 3 - 40\% Buffer B for 70 min, 90\% Buffer B for 5 min, and $3 \%$ Buffer B for $7 \mathrm{~min}$. The data acquisition protocol in the mass spectrometer was set to positive ion mode, and the addition of formic acid to the buffers was used in order to promote protonation. Peptides were selected by the mass spectrometer for further tandem MS/MS due to observed charge states of +2 and +3 .

\section{Data analysis}

Mass spectrometry data analysis, peak list conversion, peptide identification and quantitation was carried out using the combination of Analyst QS ver. 1.1 (ABSciex, Foster City, CA) and Phenyx 2.6 (Geneva Bioinformatics, Geneva, Switzerland) software against the UniProt Synechocystis (accessed May 2010). The databases used for searching were Synechocystis PCC6803 (including plasmids), and the NCBI non-redundant database (www. ncbi.nlm.nih.gov/, Accessed 01/07/10). Searches of the Synechocystis database were conducted using a targetdecoy approach (reversed sequence decoy). All searches were performed with the parameter settings: 0.1 Da MS scan tolerance, 0.15 Da MS/MS scan tolerance, strict trypsin cleavage with one allowable missed cleavage and a minimum of $20 \%$ of combined $y, y^{2+}, b, b^{2+}$ ions. Acceptance threshold for peptide identification were set to $\mathrm{p}$-value $\leq 1 \times 10^{-4}$ with a peptide score $\geq 5$. Protein identification was then set to include only matches with at least a score of 7 (AC score $\geq 7$ ).

Statistical inference was obtained using a $t$-test comparison between the reporter ions' intensities, as previously detailed in Mukherjee et al. [68] and Pham et al. 
[69]. Within this study, we include observations made with and without a Bonferonni correction.

A principal component analysis (PCA) and a hierarchical clustering were performed on the proteomic data using Mathematica (Wolfram Research) so as to provide an appreciation of biological/stress variation (see Additional file 1: Figures S3 and Additional file 1: Figure S4). These two analyses were carried out on proteins quantified with three or more MS/MS scans. For the PCA, the first two principal components were used; the clustering analysis used Ward's linkage method.

\section{Additional files}

Additional file 1: Figure S1. Growth curves for Synechocystis PCC6803 grown in $\mathrm{P}_{\mathrm{i}}$ replete medium (green circles), $3 \% \mathrm{P}_{\mathrm{i}}$ medium (red triangles), and $0.3 \% \mathrm{P}_{\mathrm{i}}$ medium (purple diamonds). All cultures were in early stationary phase upon harvesting. Figure S2. Representation of the broad functional categories associated with Synechocystis PCC6803 proteins identified in this study. Figure $\mathbf{S 3}$. Hierarchical clustering of the proteomic data (log-ratios). We only used proteins for which three or more MS/MS scans were identified; Ward's linkage method was used. This shows good reproducibility of our samples. Figure S4. Principal component analysis of the proteomic data (log-ratios). The first two principal components are shown here (PC1 abscissa and PC2 ordinate). We only used proteins for which three or more MS/MS scans were identified.

Additional file 2: Table S1. Protein list.

\section{Competing interests}

The authors declare that they have no competing interests.

\section{Authors' contribution}

CAB, GM, KFR \& PCW conceived and designed the experiment, MAF, CSG \& SYO carried out the proteomic experiments and data analysis, JN carried out statistical analysis of the data, NT \& GM conducted the enzyme assays. All authors contributed to the writing of the manuscript. All authors read and approved the final manuscript.

\section{Acknowledgements}

The authors wish to acknowledge the provision of an EPSRC studentship, Advanced Research Fellowship for CAB (EP/E053556/01) and further EPSRC funding (GR/S84347/01 and EP/E036252/1). Professor Kenneth Reardon and Dr Josselin Noirel also acknowledge the Royal Academy of Engineering Distinguished Visiting Fellowship Programme.

\section{Author details}

'BSRC Mass Spectrometry and Proteomics Facility, Department of Chemistry, University of St Andrews, St Andrews KY16 9ST, UK. ${ }^{2}$ ChELSI Institute, Department of Chemical and Biological Engineering, University of Sheffield, Sheffield S1 3JD, UK. ${ }^{3}$ Agilent Technologies, Singapore, Singapore. ${ }^{4}$ School of Biomedical Sciences, University of Ulster, Coleraine, County Londonderry BT52 1SA, UK. ${ }^{5}$ Department of Chemical and Biological Engineering Colorado State University, Fort Collins, CO 80523-1370, USA.

Received: 8 June 2012 Accepted: 28 January 2013 Published: 26 February 2013

\section{References}

1. Schutz K, Happe T, Troshina O, Lindblad P, Leitao E, Oliveira P, Tamagnini P: Cyanobacterial $\mathrm{H}(2)$ production - a comparative analysis. Planta 2004, 218:350-359.

2. Frey KM, Oppermann-Sanio FB, Schmidt H, Steinbuchel A: Technical-scale production of cyanophycin with recombinant strains of Escherichia coli. Appl Environ Microbiol 2002, 68:3377-3384.
3. Lagarde $D$, Beuf $L$, Vermaas $W$ : Increased production of zeaxanthin and other pigments by application of genetic engineering techniques to Synechocystis sp. strain PCC 6803. Appl Environ Microbiol 2000, 66:64-72.

4. Burja AM, Banaigsb B, Abou-Mansourc E, Burgess JG, Wright PC: Marine cyanobacteria-a prolific source of natural products. Tetrahedron 2001, 57:9347-9377.

5. Gill RT, Katsoulakis E, Schmitt W, Taroncher-Oldenburg G, Misra J, Stephanopoulos G: Genome-wide dynamic transcriptional profiling of the light-to-dark transition in Synechocystis sp. strain PCC 6803. J Bacteriol 2002, 184:3671-3681.

6. Burja AM, Dhamwichukorn S, Wright PC: Cyanobacterial postgenomic research and systems biology. Trends Biotechnol 2003, 21:504-511.

7. Gan CS, Reardon KF, Wright PC: Comparison of protein and peptide prefractionation methods for the shotgun proteomic analysis of Synechocystis sp. PCC 6803. Proteomics 2005, 5:2468-2478.

8. Fulda S, Mikkat S, Huang F, Huckauf J, Marin K, Norling B, Hagemann M: Proteome analysis of salt stress response in the cyanobacterium Synechocystis sp. strain PCC 6803. Proteomics 2006, 6:2733-2745.

9. Wassen MJ, Venterink HO, Lapshina ED, Tanneberger F: Endangered plants persist under phosphorus limitation. Nature 2005, 437:547-550.

10. Suzuki S, Ferjani A, Suzuki I, Murata N: The SphS-SphR two component system is the exclusive sensor for the induction of gene expression in response to phosphate limitation in Synechocystis. J Biol Chem 2004, 279:13234-13240

11. Allenby NE, O'Connor N, Pragai Z, Ward AC, Wipat A, Harwood CR: Genome-wide transcriptional analysis of the phosphate starvation stimulon of Bacillus subtilis. J Bacteriol 2005, 187:8063-8080.

12. Kocan M, Schaffer S, Ishige T, Sorger-Herrmann U, Wendisch VF, Bott M: Two-component systems of Corynebacterium glutamicum: deletion analysis and involvement of the PhoS-PhoR system in the phosphate starvation response. J Bacteriol 2006, 188:724-732.

13. Martiny AC, Coleman ML, Chisholm SW: Phosphate acquisition genes in Prochlorococcus ecotypes: evidence for genome-wide adaptation. Proc Natl Acad Sci U S A 2006, 103:12552-12557.

14. Eymann C, Mach H, Harwood CR, Hecker M: Phosphate-starvationinducible proteins in Bacillus subtilis: a two-dimensional gel electrophoresis study. Microbiology 1996, 142:3163-3170.

15. Antelmann H, Scharf C, Hecker M: Phosphate starvation-inducible proteins of Bacillus subtilis: proteomics and transcriptional analysis. J Bacteriol 2000, 182:4478-4490.

16. Madhusudhan KT, McLaughlin R, Komori N, Matsumoto H: Identification of a major protein upon phosphate starvation of Pseudomonas aeruginosa PAO1. J Basic Microbiol 2003, 43:36-46.

17. He Z, Zhong H, Hu Y, Xiao S, Liu J, Xu J, Li G: Analysis of differentialexpressed proteins of Acidithiobacillus ferrooxidans grown under phosphate starvation. J Biochem Mol Biol 2005, 38:545-549.

18. Fuszard MA, Wright PC, Biggs CA: Cellular acclimation strategies of a minimal picocyanobacterium to phosphate stress. FEMS Microbiol Lett 2010, 306:127-134

19. Fuszard M, Wright PC, Biggs CA: Comparative quantitative proteomics of Prochlorococcus ecotypes to a decrease in environmental phosphate concentrations. Aquat Biosystems 2012, 8:7.

20. Tetu SG, Brahamsha B, Johnson DA, Tai V, Phillippy K, Palenik B, Paulsen IT: Microarray analysis of phosphate regulation in the marine cyanobacterium Synechococcus sp. WH8102. ISME J 2009, 3:835-849.

21. Ishige T, Krause M, Bott M, Wendisch VF, Sahm H: The phosphate starvation stimulon of Corynebacterium glutamicum determined by DNA microarray analyses. J Bacteriol 2003, 185:4519-4529.

22. Pitt FD, Mazard S, Humphreys L, Scanlan DJ: Functional characterization of synechocystis sp. Strain PCC 6803 pst1 and pst2 gene clusters reveals a novel strategy for phosphate uptake in a freshwater cyanobacterium. J Bacteriol 2010, 192:3512-3523.

23. Adams MM, Gomez-Garcia MR, Grossman AR, Bhaya D: Phosphorus deprivation responses and phosphonate utilization in a thermophilic synechococcus sp. From microbial mats. J Bacteriol 2008, 190:8171-8184

24. Orchard ED, Webb EA, Dyhrman ST: Molecular analysis of the phosphorus starvation response in Trichodesmium spp. Environ Microbiol 2009, 11:2400-2411.

25. Juntarajumnong W, Hirani T, Simpson J, Incharoensakdi A, Eaton-Rye J: Phosphate sensing in Synechocystis sp. PCC 6803: SphU and the 
SphS-SphR two-component regulatory system. Arch Microbiol 2007, 188:389-402.

26. Hirani TA, Suzuki I, Murata N, Hayashi H, Eaton-Rye JJ: Characterization of a two-component signal transduction system involved in the induction of alkaline phosphatase under phosphate-limiting conditions in Synechocystis sp. PCC 6803. Plant Mol Biol 2001, 45:133-144.

27. Morohoshi T, Maruo T, Shirai Y, Kato J, Ikeda T, Takiguchi N, Ohtake H, Kuroda A: Accumulation of inorganic polyphosphate in phoU mutants of Escherichia coli and Synechocystis sp. strain PCC6803. Appl Environ Microbiol 2002, 68:4107-4110.

28. Bhaya D, Vaulot D, Amin P, Takahashi AW, Grossman AR: Isolation of regulated genes of the cyanobacterium Synechocystis sp. strain PCC 6803 by differential display. J Bacteriol 2000, 182:5692-5699.

29. Gomez-Garcia MR, Losada M, Serrano A: Concurrent transcriptional activation of ppa and ppx genes by phosphate deprivation in the cyanobacterium Synechocystis sp. strain PCC 6803. Biochem Biophys Res Commun 2003, 302:601-609.

30. Chong PK, Gan CS, Pham TK, Wright PC: Isobaric tags for relative and absolute quantitation (iTRAQ) reproducibility: implication of multiple injections. J Proteome Res 2006, 5:1232-1240.

31. Gan CS, Chong PK, Pham TK, Wright PC: Technical, experimental and biological variations in isobaric tags for relative and absolute quantitation (iTRAQ). J Proteome Res 2007, 6:821-827.

32. Osorio $G$, Jerez CA: Adaptive response of the archaeon Sulfolobus acidocaldarius BC65 to phosphate starvation. Microbiology 1996, 142:1531-1536.

33. Ticconi CA, Delatorre CA, Abel S: Attenuation of phosphate starvation responses by phosphite in Arabidopsis. Plant Physiol 2001, 127:963-972

34. Ray JM, Bhaya D, Block MA, Grossman AR: Isolation, transcription, and inactivation of the gene for an atypical alkaline phosphatase of Synechococcus sp. strain PCC 7942. J Bacteriol 1991, 173:4297-4309.

35. Doonan BB, Jensen TE: Physiological aspects of alkaline phosphatase in selected cyanobacteria. Microbios 1980, 29:185-207.

36. Bacsi I, Vasas G, Suranyi G, M-Hamvas M, Mathe C, Toth E, Grigorszky I, Gaspar A, Toth S, Borbely G: Alteration of cylindrospermopsin production in sulfate- or phosphate-starved cyanobacterium Aphanizomenon ovalisporum. FEMS Microbiol Lett 2006, 259:303-310.

37. MacColl R: Cyanobacterial phycobilisomes. J Struct Biol 1998, 124:311-334.

38. Allen MM, Smith AJ: Nitrogen chlorosis in blue-green algae. Arch Microbiol 1969, 69:114-120.

39. Elmorjani K, Herdman M: Metabolic control of phycocyanin degradation in the cyanobacterium synechocystis PCC 6803: a glucose effect. J Gen Microbiol 1987, 133:1685-1694.

40. Battchikova N, Vainonen JP, Vorontsova N, Keranen M, Carmel D, Aro E-M: Dynamic changes in the proteome of synechocystis 6803 in response to $\mathrm{CO}_{2}$ limitation revealed by quantitative proteomics. J Proteome Res 2010 9:5896-5912.

41. Wang $\mathrm{H}-\mathrm{L}$, Postier $\mathrm{BL}$, Burnap RL: Alterations in global patterns of gene expression in synechocystis sp. PCC 6803 in response to inorganic carbon limitation and the inactivation of $\mathrm{ndhR}$, a LysR family regulator. J Biol Chem 2004, 279:5739-5751.

42. Eisenhut $M$, von Wobeser EA, Jonas L, Schubert $H$, Ibelings BW, Bauwe $H$, Matthijs HCP, Hagemann M: Long-term response toward inorganic carbon limitation in wild type and glycolate turnover mutants of the cyanobacterium synechocystis sp. strain PCC 6803. Plant Physiol 2007, 144:1946-1959.

43. Collier JL, Grossman AR: Chlorosis induced by nutrient deprivation in Synechococcus sp. strain PCC 7942: not all bleaching is the same. J Bacteriol 1992, 174:4718-4726.

44. Wegener KM, Singh AK, Jacobs JM, Elvitigala T, Welsh EA, Keren N, Gritsenko MA, Ghosh BK, Campll DG, Smith RD, Pakrasi HB: Global proteomics reveal an atypical strategy for carbon/nitrogen assimilation by a cyanobacterium under diverse environmental peturbations. Mol Cell Proteomics 2010, 9:12.

45. Seidler A: The extrinsic polypeptides of photosystem II. Biochim Biophys Acta 1996, 1277:35-60.

46. Shen JR, Inoue $Y$ : Binding and functional properties of two new extrinsic components, cytochrome c-550 and a $12-\mathrm{kDa}$ protein, in cyanobacterial photosystem II. Biochemistry 1993, 32:1825-1832.

47. Inoue-Kashino N, Kashino Y, Satoh K, Terashima I, Pakrasi HB: PsbU provides a stable architecture for the oxygen-evolving system in cyanobacterial photosystem II. Biochemistry 2005, 44:12214-12228.
48. Kashino Y, Lauber WM, Carroll JA, Wang Q, Whitmarsh J, Satoh K, Pakrasi HB: Proteomic analysis of a highly active photosystem II preparation from the cyanobacterium synechocystis sp. PCC 6803 reveals the presence of novel polypeptides. Biochemistry 2002, 41:8004-8012.

49. Dobakova M, Sobotka R, Tichy M, Komenda J: Psb28 Protein is involved in the biogenesis of the photosystem II inner antenna CP47 (PsbB) in the cyanobacterium synechocystis sp. PCC 6803. Plant Physiol 2009, 149:1076-1086.

50. van Thor JJ, Gruters OWM, Matthijs HCP, Hellingwerf KJ: Localization and function of ferredoxin:NADP + reductase bound to the phycobilisomes of Synechocystis. EMBO J 1999, 18:4128-4136.

51. Stryer L: Biochemistry. 4th edition. New York: W.H. Freeman Co; 1995

52. Osanai T, Imamura S, Asayama M, Shirai M, Suzuki I, Murata N, Tanaka K: Nitrogen induction of sugar catabolic gene expression in synechocystis sp. PCC 6803. DNA Res 2006, 13:185-195.

53. Clarke AK: ATP-dependent Clp proteases in photosynthetic organismsa Cut above the rest! Ann Bot 1999, 83:593-599.

54. Clarke A: Variations on a theme: combined molecular chaperone and proteolysis functions in Clp/HSP100 proteins. J Biosci 1996, 21:161-177.

55. Clarke AK, Eriksson M-J: The cyanobacterium Synechococcus sp. PCC 7942 possesses a close homologue to the chloroplast ClpC protein of higher plants. Plant Mol Biol 1996, 31:721-730.

56. Stanne TM, Pojidaeva E, Andersson Fl, Clarke AK: Distinctive types of ATPdependent Clp proteases in cyanobacteria. J Biol Chem 2007, 282:14394-14402.

57. Pandhal J, Wright PC, Biggs CA: A quantitative proteomic analysis of light adaptation in a globally significant marine cyanobacterium Prochlorococcus marinus MED4. J Proteome Res 2007, 6:996-1005.

58. Oliver MJ: Desiccation tolerance in vegetative plant cells. Physiol Plant 1996, 97:779-787.

59. Bannister JV, Bannister WH, Rotilio G: Aspects of the structure, function, and applications of superoxide dismutase. CRC Crit Rev Biochem 1987, 22:111-180.

60. Singh SC, Sinha RP, Hader D-P: Role of lipids and fatty acids in stress tolerance in cyanobacteria. Acta Protozool 2002, 41:297-308.

61. Bandyopadhyay U, Das D, Banerjee RK: Reactive oxygen species: oxidative damage and pathogenesis. Curr Sci 1999, 77:658-666.

62. Hudson JJ, Taylor WD, Schindler DW: Phosphate concentrations in lakes. Nature 2000, 406:54-56.

63. Marcus Y, Gurevitz M: Activation of cyanobacterial RuBP-carboxylase /oxygenase is facilitated by inorganic phosphate via two independent mechanisms. Eur J Biochem 2000, 267:5995-6003.

64. Allen MM: Simple conditions for growth of unicellular blue-green algae on plates. J Phycol 1968, 4:1-4.

65. Axmann IM, Kensche P, Vogel J, Kohl S, Herzel H, Hess WR: Identification of cyanobacterial non-coding RNAs by comparative genome analysis. Genome Biol 2005, 6:R73.

66. O'Loughlin SN, Graham RL, McMullan G, Ternan NG: A role for carbon catabolite repression in the metabolism of phosphonoacetate by Agromyces fucosus Vs2. FEMS 2006

67. Fiske $\mathrm{CH}$, SubbaRow Y: The colourimetric determination of phosphorus. J Biol Chem 1925, 66:375-400.

68. Mukherjee J, OW SY, Noirel J, Biggs CA: Quantitative protein expression and cell surface characteristics of Escherichia coli MG1655 biofilms. Proteomics 2011, 11:339-351.

69. Pham TK, Roy S, Noirel J, Douglas I, Wright PC, Stafford GP: A quantitative proteomic analysis of biofilm adaptation by the periodontal pathogen Tannerella forsythia. Proteomics 2010, 10:3130-3141.

doi:10.1186/2046-9063-9-5

Cite this article as: Fuszard et al:: The quantitative proteomic response of Synechocystis sp. PCC6803 to phosphate acclimation. Aquatic Biosystems 2013 9:5 